\title{
EDUCAÇÃO LINGUÍSTICA CRÍTICA E A PRODUÇÃO DIGITAL DE INFOGRÁFICOS POR ALUNOS DO ENSINO MÉDIO TÉCNICO COM TEMÁTICAS CONTRA HOMOFOBIA ${ }^{1}$
}

CRITICAL LANGUAGE EDUCATION AND DIGITAL PRODUCTION OF INFOGRAPHICS BY HIGH SCHOOL TECHNICAL STUDENTS WITH THEMES AGAINST HOMOPHOBIA

\author{
Rosivaldo Gomes \\ Universidade Federal do Amapá, Brasil \\ rosivaldounifap12@gmail.com \\ Heloane Baia Nogueira \\ Universidade Federal do Amapá, Brasil \\ helobia84@gmail.com
}

\begin{abstract}
RESUMO: Este artigo apresenta resultados de um estudo que visou investigar práticas de produção textual digital do gênero discursivo hipermidiático infográfico, envolvendo multiletramentos e educação linguística crítica e cidadã com alunos do Ensino Médio Técnico de um instituto técnico federal, na região norte do Brasil. Para fundamentação teórica, consideramos as discussões sobre educação linguística em uma perspectiva crítica, teorizações sobre a pedagogia dos (multi)letramentos e a aprendizagem por design. A pesquisa, de caráter qualitativo-interpretativo, configurou-se uma pesquisa-ação. O corpus analisado é composto por recortes da produção textual de um exemplar de um infográfico interativo que foi elaborado por alunos de um curso de mineração. Os resultados da análise demonstram que os aprendizes, além de se apropriarem de práticas de multiletramentos digitais para produção técnica dos textos, também despenharam papel de analistas críticos diante da temática trabalhada no que diz respeito ao combate à homofobia.
\end{abstract}

PALAVRAS-CHAVE: Educação linguística crítica. Ensino. Produção textual. Infográficos.

\begin{abstract}
This paper presents results of a study that aimed at investigating digital textual production practices of the hypermedia discursive genre 'infographic', involving multiliteracies and critical linguistic education and citizen with technical high school students from a federal technical institute in northern Brazil. For theoretical foundation, we consider the discussions on linguistic education in a critical perspective, theorizations about the Pedagogy of (Multi)literacies and Learning by Design. The qualitativeinterpretative research was configured as an action research. The analyzed corpus is composed of excerpts from the textual production of a copy of an interactive infographic that was prepared by students of a mining course. The results of the analysis show that the students, in addition to appropriating practices of digital multiliteracies for the technical production of the texts, also played the role of critical analysts in the face of the theme about fighting homophobia.
\end{abstract}

KEYWORDS: Critical language education. Teaching. Textual production. Infographics.

1 Os dados apresentados e analisados neste artigo foram gerados durante as aulas da disciplina de Língua Portuguesa ministradas pela segunda autora, no ano de 2017 no Instituto Federal de Educação Ciência e Tecnologia do Amapá (IFAP-Campus Macapá). 


\section{Introdução}

Pensar a educação linguística no ensino de língua para o atual contexto de transformações e mudanças tanto culturais quanto sociais, identitárias e tecnológicas é também pensar como esse tema tem transgredido o próprio espaço de discussões sobre processos de ensino-aprendizagem e se relacionado com outros temas igualmente importantes para o ensino, tais como questões de identidades sociais, pois conforme destaca Ferreira (2018, p. 44) "entender que as identidades sociais de raça e de classe social são indissociáveis quando se trata da aprendizagem e do uso de uma língua é imprescindível para o exercício da educação linguística crítica".

Nesse sentido, em uma perspectiva ampla de educação linguística (crítica e cidadã), é possível que os alunos, com a mediação do professor, possam aprender não só na prática escolar, mas transpor para fora dela também, princípios de escolhas éticas na compreensão de discursos com os quais estão em contato e que circulam socialmente, podendo aprender, assim, a problematizar discursos hegemônicos de globalização e de significados antiéticos que desrespeitam as diferenças tanto culturais quanto identitárias (MOITA LOPES, 2002; 2006) mantidas nesses discursos e que ferem os direitos humanos.

Considerando essa visão, o objetivo deste artigo é apresentar alguns resultados de uma pesquisa-ação desenvolvida pelo Núcleo de Estudos e Pesquisa Interdisciplinares em Linguística Aplicada da Universidade Federal do Amapá (NEPLA/UNIFAP-CNPq), que visou investigar práticas de produção textual a partir da produção de exemplares do gênero discursivo hipermidiático infográfico envolvendo multiletramentos e práticas de letramentos digitais no trabalho de ampliação da educação linguística (crítica e cidadã) de alunos do Ensino Médio Técnico de uma escola pública federal, localizada na região norte do Brasil.

A partir desse objetivo, intentamos também, neste texto, discutir como os sujeitos participantes da pesquisa se apropriaram dos conceitos estudados para a produção dos infográficos hipermidiáticos e como se posicionaram diante do tema da homofobia em suas produções. Para fundamentação teórica, consideramos as discussões sobre educação linguística em uma perspectiva crítica, letramento crítico e as teorizações sobre multiletramentos.

A pesquisa, de caráter qualitativo-interpretativo, caracterizou-se como uma pesquisa-ação (THIOLLENT, 1994) e o corpus analisado é composto por recortes da produção textual de por um exemplar de infográficos que foram elaborados nas aulas de língua materna por alunos de um curso técnico de mineração no Instituto Federal de Educação Ciência e Tecnologia do Amapá (IFAP-Campus Macapá).

O texto está organizado em quatro seções além da introdução. Na primeira seção, tratamos da ampliação da ideia de educação linguística para uma perspectiva crítica e cidadã. Na segunda seção, exibimos uma discussão sobre a Pedagogia dos Multiletramentos e da Aprendizagem por design bem como alguns conceitos sobre infografia. Em seguida, apresentamos a metodologia e o contexto de geração dos dados. Por fim, trazemos a análise dos excertos de atividades do material didático utilizado durante a realização da pesquisa e recortes da produção textual de um exemplar dos infográficos que foram elaborados por alunos de um curso de mineração. Logo em seguida, apresentamos algumas considerações finais. 


\section{Educação linguística em uma perspectiva crítica e cidadã}

Pesquisas, discursos e dados governamentais sobre práticas escolares no contexto brasileiro, em especial sobre língua portuguesa e seus objetos/eixos de ensino (leitura, escrita, oralidade, produção textual e análise linguística/semiótica), têm evidenciado e levantado inúmeras questões e inquietudes de professoras e professores sobre a falta de interesse dos alunos pelo conteúdo trabalhado na escola ou, até mesmo, dúvidas sobre o que ensinar diante das "cobranças do novo currículo" do Ensino Médio e do efeito retroativo do Exame Nacional do Ensino Médio (ENEM) no ensino da disciplina de Língua Portuguesa.

Essas questões demonstram também que muitas ações didáticas realizadas nas práticas do letramento escolar ainda se mantêm presas a um currículo tradicional que pouco contribui para a formação cidadã - e crítica - dos alunos. Dito de outra maneira, saberes que vão além dos letramentos vernaculares (HAMILTON, 2002) quase não têm espaço em sala de aula. Isso se refere, dentre outros, aos saberes que têm suas origens na vida cotidiana dos alunos, às suas comunidades e espaços de reexistência (SOUZA, 2011) e sobrevivência (MAIA, 2015).

A respeito disso, Rojo (2008, p. 586-587) salienta que

o letramento escolar tal como o conhecemos, voltado principalmente para práticas de leitura e escrita de textos em gêneros escolares (anotações, resumos, resenhas, ensaios, dissertações, descrições, narrações e relatos, exercícios, instruções, questionários, dentre outros) e para alguns poucos gêneros escolarizados advindos de outras esferas (literária, jornalística, publicitária) não será suficiente [...]. Será necessário ampliar e democratizar tanto as práticas e eventos de letramento que têm lugar na escola como o universo de textos e gêneros que nela circulam.

Mas como ofertar relevância a saberes sejam eles locais ou globais, institucionais ou vernaculares no contexto escolar? E como trabalhar práticas de linguagem que considerem os mais variados usos sociais que envolvem leitura e escrita (letramentos) na contemporaneidade de maneira ética, crítica e democrática a partir das tecnologias digitais disponíveis? Para auxiliar na compreensão desses questionamentos, consideramos que a ideia de educação linguística crítica - e cidadã - seja um caminho possível para se pensar práticas didáticas que possam ajudar a ponderarmos sobre 0 ensino de língua portuguesa para um trabalho mais reflexivo e crítico com e sobre a língua(gem).

Nesse sentido, concordamos com a visão de Rojo e Moita Lopes (2004) ao salientarem que, para que a escola e, consequentemente alunos e professores, possa dar conta das práticas contemporâneas envolvidas no ato de ler, de produção e edição textual, de seleção e utilização de informações de forma crítica, ética e reflexiva, ela deve considerar, não necessariamente nessa sequência, três grandes conjuntos de ações que, grosso modo, podem auxiliar o trabalho de educação linguística em sala de aula: a) os letramentos múltiplos e multiletramentos, que dizem respeito à incorporação dos letramentos de culturas locais e de seus agentes, colocando as alunas, os alunos e as professoras e professores em contato com práticas de letramentos valorizados e institucionais; b) os letramentos multissemióticos, que envolvem os textos 
contemporâneos que circulam atualmente e que são potencializados cada vez mais pelas tecnologias, recursos e plataformas digitais e c) os letramentos críticos e protagonistas, que dizem respeito ao trato ético dispensado aos discursos e seus efeitos nas práticas sociais e discursivas existentes hoje em nossa sociedade pós-moderna (ROJO; MOITA LOPES, 2004).

Todavia, consideramos também que a visão de educação linguística que hoje fundamenta o ensino de línguas na escola precisa ser ampliada também para que as professoras e os professores possam transgredir certas ações já sedimentadas e atuarem como agentes transformadores (BELL HOOKS², 2013[1994]) da realidade do ensino que praticam.

Dessa maneira, para Bagno e Rangel (2005), a educação linguística configura-se um conjunto de fatores socioculturais que, durante toda a existência de um indivíduo, Ihe possibilitam adquirir, desenvolver e ampliar o conhecimento de/sobre sua língua materna, de/sobre outras línguas, sobre a linguagem de um modo mais geral e sobre os demais sistemas semióticos. É perceptível, nessa visão dos autores, que a educação linguística também envolve práticas de letramentos que estão presentes na sociedade e que são sustentadas por ideologias definidoras do que é língua/linguagem e o que compõe o que os autores denominam "imaginário linguístico".

Ainda para Bagno e Rangel (2005), a educação linguística, assim como outras instâncias de poder que constituem o Estado-Nação, faz parte de formações discursivas (FOUCAULT, 1997) que a formalizam, a sistematizam e a institucionalizam. Entretanto, em uma perspectiva de educação preocupada com a cidadania global a partir de "bases desnaturalizadoras e pós-colonialistas" (MENEZES DE SOUZA, 2012), concordamos com a visão de educação linguística pluralista, crítica ou democrática (ROCHA; AZZARI, 2016), fortemente discutida pelos estudos da Linguística Aplicada Crítica e pelos estudos do Letramento Crítico e, às vezes, praticadas pelas professoras e pelos professores nas brechas do currículo (DUBOC, 2015) ${ }^{3}$.

Dessa maneira, em uma perspectiva crítica,

a educação linguística, orientada para a cidadania global sob o viés crítico ou póscolonialista, por conseguinte, permite a abertura para o desconhecido, possibilitando o rompimento com ontologias e epistemologias, políticas e práticas (educacionais) que reproduzam, mesmo que de forma não intencional, referenciais, discursos e representações etnocêntricas, a-históricas e centralizadoras. (ROCHA; AZZARI, 2016, p. 159).

Nessa visão de educação linguística de caráter democrático ou crítico, conforme Rocha e Azzari (2016), o trabalho com o ensino de línguas, nas práticas do letramento escolar, não deve se limitar à padronização e normatividades que tomem como objeto central para o ensino apenas estruturas linguísticas/gramaticais. Ao contrário, nessa visão prima-se pela "desconstrução de normatividades, pela desestabilização, sem negligenciar

2 O pseudônimo é uma homenagem de Gloria Jean Watkins escritora norte-americana nascida em 25 de setembro de 1952, no Kentucky - EUA. Apelido esse que escolheu para assinar as obras e que é uma homenagem aos sobrenomes da mãe e da avó.

3 Em nossas experiências como formadores de professores em cursos de formação continuada, como o Pacto Nacional pelo Fortalecimento do Ensino Médio (BRASIL, 2013), foi possível vivenciar isso a partir de diálogos com professores que realizavam formações na universidade. 
o direito de cada um à igualdade de acesso a saberes socialmente valorizados" (ROCHA; AZARRI, 2016, p. 163), entre eles os saberes linguísticos, discursivos ou pragmáticos envolvidos na produção, no consumo e na distribuição de textos em variadas práticas discursivas.

Ampliando mais ainda essa visão, consideramos importante a compreensão de educação linguística na perspectiva da criticidade proposta por Ferreira (2018) e Pereira (2018). Para esses autores, a educação linguística crítica não visa somente o posicionamento de educadoras e educadores como formadores de pessoas capazes de fazer uso da língua para se comunicar em diversas práticas de letramento e de maneira proficiente, mas os vê, também, como formadores de sujeitos "que se situam em um contexto sociopolítico, cultural e econômico, no qual devem atuar como agentes de transformação e mudança social" (PEREIRA, 2018, p. 53).

Em direção semelhante, Monte Mór (2018) e Jordão (2018) também defendem que pensar o ensino de línguas em uma perspectiva crítica, e nesse caso de educação linguística, é considerar o engajamento de todos os sujeitos implicados nesse processo (alunas[os] e professoras[res]), não apenas como agentes passivos de aprendizagem ou no termo sabiamente problematizado por Freire (2003) - aprendizes de uma educação bancária - nem tampouco como agentes detentores dos saberes, mas ao contrário, é considerar a implicação dos sujeitos no mundo. Ou seja,

a educação linguística crítica pressupõe sujeitos associativos, que relacionam dimensões do saber linguístico a práticas que elas podem estar informando, e que associam as práticas com que têm contato a perspectivas epistemológicas e ontológicas que as tornam possíveis. (JORDÃO, 2018, p, 78).

Na perspectiva da educação linguística crítica, portanto, os saberes intrínsecos à língua (saber linguístico) não são anulados, mas considerados, pois esses também estão no "engajamento com os processos de construção de sentidos [...] em uma perspectiva crítica" (JORDÃO, 2018, p. 77), já que língua é discurso, é prática social carregada de ideologias.

Nessa perspectiva, é essencial uma educação linguística que se caracterize como aberta e sensível às diferenças, não só de aprendizagem e de modos de ensinar, mas também em relação às identidades sociais de raça, de gênero, de classes sociais, de sexualidades, que se presentificam nas salas de aula. Além disso, é preciso considerar uma educação linguística que possa problematizar, questionar e buscar romper com visões totalitárias e reducionistas de língua/linguagem, de sujeitos, pois nesse sentido ela

(...) pode colocar em xeque o status quo, desconstruir discursos racistas, homofóbicos, xenofóbicos, misóginos e classistas. $E$, através das reflexões que ocorrem a partir das observações das práticas sociais e do cotidiano, podemos conseguir reconstruir práticas de empoderamento e críticas através da linguagem. (FERREIRA, 2018, p. 45).

Assim, a partir de uma educação linguística crítica e cidadã, conforme estamos defendendo neste texto, discursos forjados nos textos em circulação e que adentram a escola, podem ser problematizados nas aulas de línguas/linguagens. Em termos práticos, para se pensar essa educação linguística e realizá-la nas práticas do letramento escolar, 
é necessário que também estejamos atentos aos nossos alunos e alunas bem como às suas identidades sociais (de gênero, de raça, de classes). Isso envolve, inevitavelmente, que compreendamos, entendamos e reconheçamos, em um movimento de alteridade, "que o outro, primeiro tem necessidades diversas e que precisa ser entendido para que, depois, sim, possa se interessar em aprender uma língua que se comunica com ele/a" (FERREIRA, 2018, p. 45), ou seja, que percebamos o outro em suas especificidades, sejam elas de aprendizagem ou não, pois aprender uma língua também envolve essas questões.

\section{3 (Multi)letramentos e a aprendizagem pelo design}

A composição multi-hipermidiática (SIGNORINI, 2012) que constitui os textos contemporâneos, caracterizando-os como multissemióticos ou multimodais, apresenta-se como um tema recorrente hoje nos estudos da Linguística Aplicada e também em pesquisas voltadas para o ensino-aprendizagem de línguas que tomam como base central, tanto para discussão teórica quanto analítica, os diversos princípios/conceitos da Teoria ou Pedagogia dos Multiletramentos.

A expressão "multiletramentos" ganha destaque no contexto do final dos anos 90, a partir da publicação, em 1996, de um manifesto denominado "A Pedagogia dos multiletramentos: desenhando futuros sociais". Esse texto ficou conhecido como o manifesto seminal dessa proposta e foi produzido por um grupo de estudiosos dos letramentos, dentre os quais americanos, ingleses e australianos, que foi chamado de Grupo de Nova Londres - GNL.

Quatro anos mais tarde, em 2000, Cope e Kalantzis (2000), membros do grupo, apresentaram uma reedição do manifesto de 1996 e uma nova obra incluindo novos textos produzidos por alguns integrantes do GNL e por educadores interessados em discutir práticas de ensino a partir da perspectiva de multiletramentos.

Assim, de modo geral, podemos dizer que a configuração central do GNL fundavase no fato de que, diante das mudanças socioculturais e digitais pelas quais a sociedade estava passando, a escola deveria ampliar sua visão de letramento ou "pedagogia do letramento", centrada até então em práticas grafocêntricas (SIGNORINI, 2012), para os novos letramentos (multiletramentos). Para isso, deveria considerar dois princípios centrais dessa pedagogia: a multiplicidade cultural e linguística, isto é, o contato linguístico e étnico-racial/cultural acentuado nos países de língua inglesa e a multiplicidades de linguagens configurados nos novos textos.

Contudo, conforme Rojo (2012), pesquisadora dos estudos dos multiletramentos no Brasil, os pesquisadores do GNL direcionaram seu olhar para as diversidades culturais no contexto do "Norte Global" (SANTOS, 2007), pois essas se faziam presentes nas salas de aula a partir, principalmente, do processo de globalização que o mundo já estava passando no momento da construção do manifesto da pedagogia dos multiletramentos.

Em nossa realidade brasileira, especialmente no contexto de investigação desta pesquisa, a ideia de diferenças culturais é mais local, situada e relacionada com as identidades sociais e culturais dos alunos, as quais dizem respeito à etnia (negros, quilombolas, indígenas, mestiços, ribeirinhos, da área rural), ao gênero e orientação sexual (cisgênero, transexual e/ou transgênero, binário, heterossexual, homossexual, 
bissexual), ao perfil e ao grupo socioeconômico e suas inserções em diversas práticas e eventos de letramentos (digitais, locais, regionais, religiosas ${ }^{4}$, etc.).

Nesse sentido, vemos que a constituição dessa diversidade linguístico-cultural ou de diferenças interculturais, "concebidas como realidades sociohistóricas, em processo contínuo de construção-desconstrução-construção" (CANDAU, 2008, p. 246), também é marcada localmente, mas inevitavelmente conectada com o global.

Para um trabalho com multiletramentos, a escola deve partir "das culturas de referência do alunado (popular, local, de massa) e de gêneros, mídias e linguagens por eles conhecidos, para buscar um enfoque crítico, pluralista, ético e democrático" (ROJO, 2012, p. 8) e nessa perspectiva, seja no direcionamento da diversidade cultural ou das múltiplas linguagens que constituem os textos contemporâneos, os multiletramentos caracterizam-se da seguinte maneira: a) interativos (colaborativos); b) rompem e transgridem relações de poder estabelecidas e c) configuram-se como híbridos, fronteiriços, mestiços - de linguagens, modos, mídias e culturas (ROJO, 2012).

O segundo princípio, levantado pelos pesquisadores do GNL, diz respeito à multiplicidade de linguagens, isto é, a variedade crescente dos textos cada vez mais multissemióticos e que estão surgindo, principalmente, em função da ampliação dos recursos e dispositivos oriundos das tecnologias digitais e da web 2.0, o que implica, para o trabalho com o letramento escolar, compreender como esses textos são produzidos e funcionam em práticas de letramentos digitais e como podem se constituir como potenciais objetos didáticos para o processo de ensino-aprendizagem de línguas a fim de que o aluno possa, conforme defende a Base Nacional Curricular Comum (BNCC):

(...) apropriar-se das linguagens da cultura digital, dos novos letramentos e dos multiletramentos para explorar e produzir conteúdo em diversas mídias, ampliando as possibilidades de acesso à ciência, à tecnologia, à cultura e ao trabalho (...) [e] mobilizar práticas de linguagem no universo digital, considerando as dimensões técnicas, críticas, criativas, éticas e estéticas, para expandir as formas de produzir sentidos, de engajar-se em práticas autorais e coletivas, e de aprender a aprender nos campos da ciência, cultura, trabalho, informação e vida pessoal e coletiva. (BRASIL, 2018, p. 475/490).

Além disso, os pesquisadores do grupo trazem o conceito de design de significados. Esse conceito estabelece uma concepção muito mais dinâmica de representação, de linguagem, de aprendizagem, de mundo, de significados, sendo classificado como ato de construção/reconstrução de sentidos (COPE; KALANTZIS, 2009). Possui, assim, duas principais características de sentidos: a estrutura (sistemas, formas e convenções de sentido) e o ato de construção de sentido (processo criativo em que o sujeito, definido como meaning-maker, constrói e representa sentidos, tornando-se agente ativo, designer de sentidos, e não mais somente espectador dos sentidos que são criados pelos outros).

A partir dessas teorizações sobre as novas configurações do letramento, os pesquisadores do grupo GNL (COPE; KALANTZIS, 2006) propuseram alguns encaminhamentos ou "movimentos pedagógicos" para a didatização de uma proposta de

4 Como exemplo disso, podemos citar alunos pertencentes a comunidades quilombolas que participam de rodas de Marabaixo, "dança dramático-religiosa de cortejo afrodescendente". Conforme Videira (2009), o termo designa a identidade étnica do negro amapaense. 
ensino a partir de uma pedagogia de multiletramentos: prática situada, instrução explícita, enquadramento crítico e prática transformada. Esses movimentos pedagógicos caracterizam-se conforme Quadro 1:

Quadro 1: Síntese dos componentes da Pedagogia dos Multiletramentos.

\begin{tabular}{|c|c|c|c|}
\hline Prática Situada & Instrução Explícita & Enquadramento Crítico & Prática Transformada \\
\hline $\begin{array}{l}\text { Caracteriza-se como a } \\
\text { imersão na experiência e } \\
\text { utilização de Designs de } \\
\text { significado disponíveis, } \\
\text { incluindoraqueles } \\
\text { relacionados à } \\
\text { experiência de vida dos } \\
\text { alunos e simulações dos } \\
\text { relacionamentos a serem } \\
\text { encontrados em espaços } \\
\text { profissionais e públicos. }\end{array}$ & $\begin{array}{l}\text { Compreensão } \\
\text { sistemática, analítica e } \\
\text { consciente dos Designs } \\
\text { de significados e dos } \\
\text { processos de Design, o } \\
\text { que requer a introdução } \\
\text { de metalinguagem } \\
\text { explícita, que permite } \\
\text { descrever e interpretar } \\
\text { elementos de Design de } \\
\text { diferentes modalidades } \\
\text { de significados. }\end{array}$ & $\begin{array}{l}\text { Interpretação do contexto } \\
\text { social e cultural de } \\
\text { designs particulares de } \\
\text { significados, o que } \\
\text { envolve o distanciamento } \\
\text { dos alunos do objeto de } \\
\text { estudo/discussão para o } \\
\text { visionamento crítico em } \\
\text { relação ao contexto. }\end{array}$ & $\begin{array}{l}\text { Configura-se prática de } \\
\text { ressignificação } \\
\text { prática/ação educativa, o } \\
\text { que permite que os } \\
\text { significados } \\
\text { transformados } \\
\text { (redesigned) } \\
\text { trabalhados em outros } \\
\begin{array}{ll}\text { contextos e espaços } \\
\text { culturais. }\end{array}\end{array}$ \\
\hline
\end{tabular}

Fonte: Adaptado de GNL (1996).

Consideramos que esses movimentos pedagógicos, conforme defendido por Cope e Kalantzis (2000) e pelo GNL (1996), muito podem auxiliar o ensino de língua portuguesa a partir da noção de educação linguística crítica e cidadã conforme o que estamos assumindo neste trabalho, pois é necessário que formemos aprendizes capazes de se apropriar dos designs disponíveis (recursos semióticos e culturais diversos) e, para isso, é claro, devem ter competências práticas e técnicas para se tornarem usuários funcionais. Entretanto, é necessário também que sejam analistas críticos desses recursos para que serem também transformadores de sentidos.

Nesse viés, Rojo (2017, p. 9), ampliando as teorizações apresentadas pelos pesquisadores do GNL, propõe que

(...) uma pedagogia por design, na qual os estudantes precisam se apropriar dos designs digitais disponíveis, isto é, precisam, é claro, ter conhecimento prático e competência técnica para ser um "usuário funcional", mas somente isso não basta: é preciso também ser um leitor, um analista crítico desses designs disponíveis (textos, infográficos, vídeos de diversos tipos, esquemas, imagens estáticas, games etc.). Mas uma pedagogia dos multiletramentos não se esgota nos designs disponíveis: ela busca conhecê-los e analisá-los criticamente para, a partir deles, chegar ao redesign, isto é, a uma produção que se apropria do disponível conhecido para "criar sentidos transformados e transformadores".

Kalantzis e Cope (2005) após testarem os quatro movimentos pedagógicos em práticas escolares, propuseram, em 2005, a Learning by Design - Aprendizagem pelo Design. As discussões teóricas sobre essa abordagem surgem em uma obra com esse mesmo título e em outros trabalhos posteriores (COPE; KALANTZIS, 2009, 2012, 2015), nos quais os autores recategorizam os quatro movimentos iniciais da pedagogia dos multiletramentos ampliando-os para oito passos e relacionando-os com o que os autores denominaram "processos de aprendizagem": experienciar, conceitualizar, analisar e aplicar (COPE; KALANTZIS, 2009). Esses "novos" oito estágios pedagógicos constituem 
o que os autores denominam Learning by Design:

A pedagogia Learning by Design usa oito "Processos de conhecimento". Um Processo de Conhecimento é um tipo de atividade que representa uma maneira distinta de produzir conhecimento e aprender. Como projetistas de ambientes de aprendizagem, os professores podem escolher qualquer combinação e ordem de processos de conhecimento. O objetivo de indicar o Processo de Conhecimento subjacente a cada atividade é fazer com que os professores pensem explicitamente sobre a faixa e sequência de atividades de aprendizagem mais apropriadas para seus alunos e assuntos. Os professores usam os processos de conhecimento como instruções para projetar, documentar e implantar seus programas de aprendizado. Chamamos o uso consciente e considerado desses processos de conhecimento de "aprendizado por design". Nesse contexto, o professor se torna um designer reflexivo de experiências de aprendizagem (professor como designer); e os planos de sala de aula se tornam 'designs-forlearning' compartilháveis. A implantação consciente e adequada da variedade de Processos de Conhecimento visa promover habilidades de pensamento de ordem superior e aprendizado mais profundo. (COPE; KALANTZIS, 2015, p. 4).

Dessa maneira, novos designs no processo de ensino-aprendizagem dos alunos para o trabalho com práticas de leitura, produção textual (impressa, digital, multimodal) e análise/compreensão linguística-semiótica de textos multimodais/multissemióticos são mobilizados, construídos e reconstruídos em sala de aula. Assim, de acordo com o Gomes (2017a, p. 62), na reconfiguração feita por Cope e Kalantzis (2015), obtém-se: prática situada como a experienciação; instrução explícita como a conceituação; enquadramento crítico caracterizado como análise e prática transformada como aplicação. Na Figura 1 e na descrição a seguir, apresentamos uma síntese da reorganização dos quatro movimentos pedagógicos iniciais para os processos de conhecimento proposta por Kalantzis e Cope (2012):

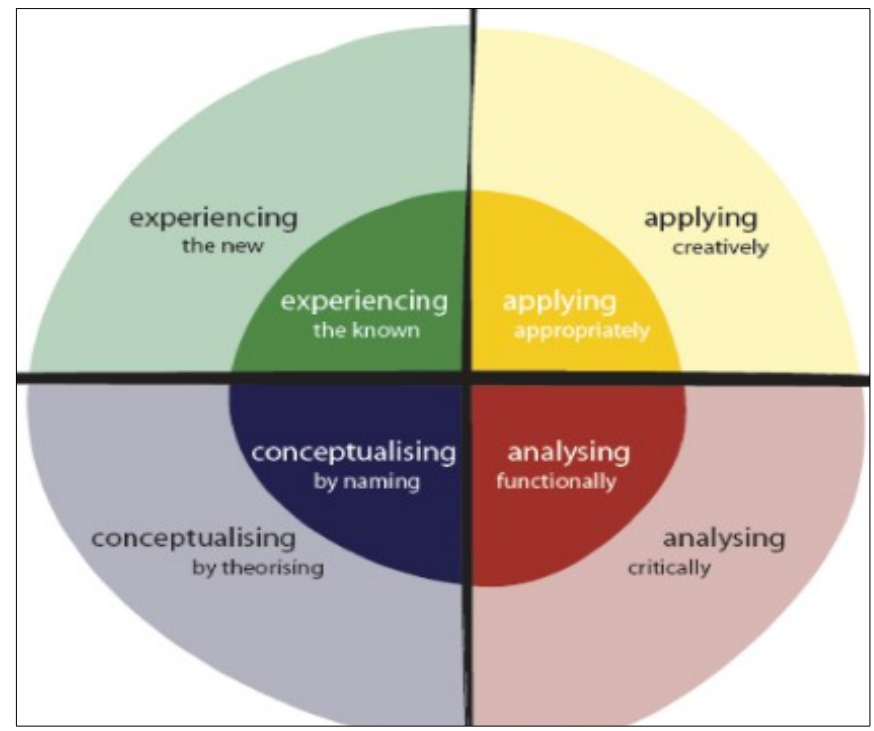

Figura 1: Processos de conhecimentos na pedagogia da aprendizagem pelo design. Fonte: Cope e Kalantzis (2015).

1. Experienciar:

> conhecido: aprendizes refletem sobre suas próprias experiências familiares, 
interesses e perspectivas.

> O novo: aprendizes observam ou participam de algo não familiar; ficam imersos em novas situações ou contextos.

2. Conceitualizar:

> Nomeando: o grupo pensa em categorias, aplica termos que classifica e define esses termos.

> Teorizando: aprendizes fazem generalizações utilizando os conceitos e conectam os termos em mapas conceituais ou teorias.

\section{Analisar:}

> Funcionalmente: aprendizes analisam conexões lógicas, causa e efeito, estrutura e função.

> Criticamente: aprendizes avaliam suas próprias perspectivas e as de outras pessoas, assim como seus interesses e motivos.

\section{Aplicar:}

> Apropriadamente: aprendizes aplicam a nova aprendizagem em situações reais do mundo e testam sua validade.

> Criativamente: aprendizes fazem uma intervenção inovadora e criativa no mundo, ou transferem o que aprenderam para um contexto diferente. (KALANTZIS; COPE, 2012, p. 518).

\subsection{Infografia hipermidiática}

De acordo com Santaella $(2014)^{5}$ a hipermídia diz respeito à combinação do hipertexto com a multimídia. Segundo a autora, o prefixo hiper, de hipertexto, corresponde às informações fragmentadas que estão além da primeira superfície do texto, mas que juntamente a esse formam uma estrutura reticular, temática que se complementa através da associação e interação dos usuários, transformando-se em versões que só são possíveis devido ao caráter não linear e multidimensional do hipertexto. Para Santaella (2014, p. 212),

\footnotetext{
O que o hipertexto nos apresenta é um texto que, em vez de se estruturar frase a frase linearmente como em um livro impresso, caracteriza-se por nós ou pontos de intersecção que, ao serem clicados, remetem a conexões não lineares, compondo um percurso de leitura que salta de um ponto a outro de mensagens contidas em documentos distintos, mas interconectados. Isso vai compondo uma configuração reticular.
}

Segundo a autora, pode parecer complexo, mas é o que o usuário faz ao ler um texto na internet e ao clicar em palavras sublinhadas ou coloridas, chamadas, no mundo

5 A autora tem preferido até mesmo a utilização do termo "hipermídia" em lugar de "letramento digital", o que não vem ao caso em nossa pesquisa. 
digital, de hiperlinks ou apenas links, para obter mais informações que estão disponíveis em outros textos. Assim, conforme Santaella (2014), a estrutura do hipertexto é multilinear e interativa. Multilinear já que vai de um ponto a outro da informação com um simples clique e interativa porque depende dos comandos do usuário-leitor, que tem agora uma participação mais ativa, podendo escolher os caminhos que quer seguir dentro do texto, selecionando pontos que o levem a outros textos para complementar o sentido de sua leitura.

A multimídia, segundo Santaella (2014), consiste na hibridação de linguagens, de processos sígnicos, códigos e mídias. Na era digital, "as telas se enchem de sinais de orientação, de imagens, fotos, desenhos, animações, sons de distintas espécies e certamente de palavras, legendas e textos" (SANTAELLA, 2014, p. 213) em uma malha híbrida de linguagens que constitui a multimídia.

De acordo Santaella (2014), ao se fundir o hipertexto com a multimídia origina-se a hipermídia, que diz respeito aos "nós" que levam a outros textos não mais de natureza unicamente verbal, mas também não verbal, como imagens, vídeos, música, etc. Com isso, a autora afirma que essa combinação densa e complexa de linguagens, tecida de "hipersintaxes multimídia" implementa uma nova forma de conceber as informações não limitada à linguagem verbal, mas aberta às possibilidades de se formarem através do som, pela visualidade e pelo discurso verbal. Segundo Santaella (2014, p. 213),

(...) a hipermídia tornou-se a linguagem que lhe é própria [da internet], uma linguagem tecida de multiplicidades, heterogeneidades e diversidades de signos que passaram a coexistir na constituição de uma realidade semiótica distinta das formas previamente existentes de linguagem.

Reforçando essa noção, ainda com base em Santaella (2014), é possível afirmar que a hipermídia é multissemiótica, sendo composta, como já vimos acima, por imagens, sons, textos, animações e vídeos que podem ser conectados em variadas associações (de acordo com a vontade do leitor), ultrapassando a ideia de um texto sequencial com começo, meio e fim pré-determinados e fixos.

Neste artigo, consideramos o gênero infográfico digital interativo um gênero hipermidiático uma vez que sua constituição contém múltiplas semioses/linguagens (multisemiose) que se revelam através do hipertexto e da multimídia. Dessa maneira, é possível perceber que não há linearidade na escrita, tampouco na leitura já que são apresentados blocos de informação ligados a palavras, imagens, vídeos e animações que, por sua vez, fornecem ao leitor possibilidades de interação. Essa interação parte de textos verbais e não verbais (tais como vídeos, músicas, animações que variam de acordo com o interesse do leitor) que venham a coexistir com o infográfico.

Nessa direção, segundo Fernández-Ladreda (2004) a infografia, em sua versão digital, é um hipertexto em si mesmo que proporciona organização e estrutura aos conteúdos mais do que somente acesso à informação verbal, isto é, apresenta, segundo o autor, "autonomia hipertextual", sendo que os infográficos digitais conferem uma interface própria para cada informação e permitem a apresentação muito mais completa da notícia, por exemplo. Para Fernández-Ladreda (2004), o infográfico constitui, assim, o melhor exemplo de notícias hipertextuais.

Para De Pablos (1999), os infográficos multimídia cumprem a função de explicar com imagens, animações e sons, temas relacionados ao conhecimento científico com detalhes e minúcias que passariam despercebidas em um texto unicamente verbal. Para 
Valero Sancho (2010), entre as principais propriedades do infográfico digital, está o relato sintético com toda autonomia e capacidade para conter realidades complexas em seu interior e permitir que a informação seja passada de maneira integral.

Como o objetivo da pesquisa era fornecer subsídios para que alunos do $3^{\circ}$ ano do Ensino Médio do IFAP pudessem produzir infográficos hipermidiáticos interativos, consideramos a classificação proposta por Ribas (2004). Para a autora, o infográfico digital interativo é um modelo composto por uma estrutura discursiva/hipermidiática que possui alguns elementos específicos de produção. São eles: tipos, estados e categorias. No caso dos tipos, um infográfico pode ser considerado autônomo ou complementar. Para ser autônomo, deve conter todos os elementos de uma notícia sem a necessidade de um texto paralelo. O texto verbal é um elemento complementar assim como as imagens, as animações, os sons, os vídeos que, integrados, constituem a própria notícia.

Em contrapartida, um infográfico complementar serve, como o próprio nome diz, para complementar uma informação à notícia principal que, por sua vez, também é apresentada na forma de um infográfico, porém autônomo, isto é, um infográfico dentro de outro infográfico. Vale destacar que aqui se considera gênero infográfico aquele que produz sentido de modo autônomo, independentemente de vir acompanhado ou não de uma reportagem ou notícia.

Quanto aos estados, Ribas (2004) aponta que os infográficos hipermidiáticos possuem dois tipos que seriam de atualidade e de memória. No caso dos infográficos hipermidiáticos de atualidade, esses são construídos no momento dos acontecimentos, já os infográficos hipermidiáticos de memória são arquivos fechados e acabados. De um jeito ou de outro, um infográfico de atualidade sempre se tornará um infográfico de memória, já que se torna arquivo quando deixa de ser atualizado.

Ainda segundo Ribas (2004), o infográfico hipermidiático também é composto por três categorias, que juntas ou separadamente podem caracterizar um infográfico hipermidiático. São elas: a categoria sequencial, a relacional e a espacial. A categoria sequencial tem como característica demonstrar um acontecimento, processo ou fenômeno em uma sequência detalhada, necessitando acompanhamento sequencial para a compreensão da totalidade. Já a categoria relacional é caracterizada por permitir interação por meio de escolhas que desencadeiem e desenvolvam determinados processos, permitindo compreender as relações entre causa e consequência. Por fim, no que diz respeito à categoria espacial, esta tem como característica a reconstituição do interior de um ambiente, tal como ele é fisicamente, permitindo um "passeio virtual".

A partir das teorizações apresentadas nesta seção, trataremos da contextualização da pesquisa realizada. Cabe destacar que para a operacionalização da pesquisa-ação consideramos, primeiramente, os princípios da pedagogia dos (multi)letramentos e a classificação de infográficos apresentada na construção de um projeto didático autoral de material de ensino, o qual foi utilizado com os alunos durante a segunda etapa da pesquisa (de campo).

\section{0 contexto de geração dos dados da pesquisa}

Conforme já informado na seção introdutória deste artigo, a pesquisa foi realizada no contexto de Educação Profissional Técnico de Nível Médio do IFAP, localizado na 
região norte do Brasil. A escolha por esse locus de pesquisa ocorreu em função da peculiaridade de formação dos educandos - Técnicos em Mineração - e, nesse contexto, o ensino da disciplina de Língua Portuguesa e Literatura é reconfigurado em função das necessidades profissionais dos alunos.

Cabe esclarecer, antes de apresentamos os procedimentos metodológicos de realização do estudo, que seguindo as recomendações da Resolução $n^{0} 510$ de 07 de abril de 2016/Conep, todos os sujeitos participantes da pesquisa receberam um Termo de Consentimento Livre e Esclarecido (TCLE) e um Termo de Assentimento, assegurando os benefícios e possíveis danos que poderiam sofrer com a pesquisa.

A pesquisa também foi registrada sob o $n^{\circ}$ PVL311-2017 no Departamento de Pesquisa da UNIFAP. Além disso, considerando que os dados gerados a partir da intervenção realizada se tornariam públicos, na análise dos dados estamos utilizando pseudônimos para a identificação dos sujeitos. Feitas as ressalvas sobre as questões éticas do estudo, para a geração de dados foi desenvolvida uma pesquisa-ação (THIOLLENT, 1994; ANDRÉ, 1995).

A pesquisa-ação, conforme propõem os autores, além de engajar o pesquisador na situação estudada e transformá-lo em um observador participante, coloca a importante questão da ação planejada no campo em estudo, visando contribuir com os participantes. Além disso, é necessário ressaltar que a ação é gerada no próprio processo de investigação, havendo assim uma estreita participação dos pesquisadores e das pessoas participantes.

Ainda conforme André (1995) e Thiollent (1994), uma pesquisa-ação configura-se, não necessariamente de forma rígida, a partir de algumas etapas. No caso da pesquisa realizada, essas etapas configuraram-se da seguinte forma:

a) Fase diagnóstica, que objetivou favorecer o conhecimento da realidade pesquisada e dos participantes, algumas de suas dificuldades de aprendizagem, sendo aplicado um questionário semiestruturado para os alunos, que continha perguntas sobre quais conhecimentos já detinham ou não sobre infográficos, usos desse gênero em outras disciplinas, se conheciam ferramentas para a produção e edição;

b) Planejamento da ação, que partiu da avaliação da realidade observada. Em nosso caso, essa fase correspondeu tanto à leitura de bases teóricas quanto à construção de um material didático, tendo por fundamento as necessidades dos alunos mapeadas a partir do diagnóstico e de conversas da professorapesquisadora com eles;

c) Execução das ações, que ocorreu a partir de oficinas de discussões coletivas sobre tipos de preconceitos e atividades de práticas de leitura, análise textual/semiótica e de produções digitais de infográficos a partir do material didático construído pelos pesquisadores e;

d) Avaliação dos resultados obtidos a partir da socialização das produções, de autoavaliações, de discussões sobre as temáticas a respeito de tipos de 
preconceito abordados e sobre o funcionamento e uso dos infográficos em práticas reais de comunicação, inclusive em suas demandas escolares.

Assim, o projeto-piloto desenvolvido ${ }^{6}$ teve como objetivo central propor atividades didáticas para se trabalhar práticas de letramentos digitais com os participantes da pesquisa por meio da produção de infográficos interativos a respeito do tema preconceito. Foram utilizados como dispositivos didáticos para geração dos dados da pesquisa, além de questionários e diário de campo, um Modelo Didático de Gênero (MDG) ${ }^{7}$ conforme proposta de De Pietro e Schneuwly (2014), que posteriormente auxiliou na construção do Projeto Didático Autoral de Ensino (PDAE).

De acordo com Gomes (2017b, p. 10), um PDAE

configura-se como um protótipo de ensino aberto (material didático impresso ou digital) que permite ao professor, em formação ou já formado, a organização, a partir de um MDG, de um conjunto de atividades sequenciadas voltadas para a didática do ensino de práticas de leitura, práticas de análise linguística (semiótica), de produção oral e práticas de produção textual a partir de processos de construção de sentidos no ensino-aprendizagem de línguas. Um projeto didático autoral fundamenta-se nas noções de língua(gem) como prática dialógica e social, marcada por índices de apreciação de valor. Além disso, convoca a ideia de gênero discursivo (BAKHTIN/VOLOCHÍNOV, 1997 [1929]), como uma construção discursiva sócio-ideologicamente situada em práticas e eventos de letramentos (STREET, 1984, 2003), que são marcadas por dimensões tanto culturais quanto ideológicas. Além dessas abordagens teóricas, na constituição do projeto autoral estão presentes também alguns princípios da Pedagogia dos Multiletramentos a partir da noção de Aprendizagem pelo Design (KALANTZIS; COPE, 2005) - que, por meio de processos de conhecimento, possibilita e direciona o aluno para uma aprendizagem significativa - não só de um gênero - mas práticas de língua(gem) com base naquilo que ele já experienciou, conceituou, analisou e aplicou ou está aplicado em práticas de letramentos.

Para a renderização do PDAE construído, utilizamos o software livre Kotobee Author, o que possibilitou a construção de um livro digital. A ferramenta foi selecionada em função de proporcionar aos usuários a possibilidade de poderem fazer criações multissemióticas/multimodais, misturando imagens, diagramas, sons, animações, vídeos, links etc. Assim, o PDAE apresenta a seguinte configuração, conforme Quadro 2:

6 O referido projeto, intitulado "Do estático ao Digital: Infográficos animados nas aulas de Língua Portuguesa", foi desenvolvido pelos dois autores deste artigo somado ao apoio da bolsista Eloiny Ptra Brasil Lazamé Nóbrega, sendo a segunda autora, à época da realização da pesquisa, professora substituta do IFAP.

7 Um MDG, em tese, funcionaria como um norte para auxiliar o processo de transposição didática [e de didatização] de um determinado gênero de textos retirados das práticas de referências/de linguagem e mobilizado para as práticas de ensino no letramento escolar, ou seja, a "construção desse modelo de gênero permitiria a visualização das dimensões constitutivas do gênero e seleção das que podem ser ensinadas e das que são necessárias para um determinado nível de ensino" (MACHADO; CRISTOVÃO, 2009, p. 123-151). 
Belo Horizonte, v. 12, n. 2, p. 32-55, mai.-ago. 2020 - ISSN 1983-3652

DOI : $10.35699 / 1983-3652.2020 .24441$

Quadro 2: Sinopse da composição didática do PDAE.

\begin{tabular}{|c|c|c|c|c|}
\hline $\begin{array}{c}\text { PROCESSOS DE } \\
\text { CONHECIMENTOS } \\
\text { DA } \\
\text { APRENDIZAGEM } \\
\text { PELO DESIGN }\end{array}$ & $\begin{array}{l}\text { PRÁTICAS DE } \\
\text { LINGUAGEMI } \\
\text { OBJETOS DE } \\
\text { ENSINO }\end{array}$ & $\begin{array}{l}\text { ATIVIDADES } \\
\text { PREVISTAS }\end{array}$ & $\begin{array}{l}\text { OBJETIVOS DE } \\
\text { APRENDIZAGEM }\end{array}$ & $\begin{array}{c}\text { PRÁTICAS DE } \\
\text { MULTILETRAMENTOS } \\
\text { ESPERADAS/DESENVO } \\
\text { LVIDAS }\end{array}$ \\
\hline $\begin{array}{l}\text { (Prática situada) } \\
\text { Usuário funcional } \\
\text { Experienciar: o } \\
\text { conhecido, o novo }\end{array}$ & $\begin{array}{c}\text { Oralidade e leitura } \\
\text { crítica }\end{array}$ & $\begin{array}{c}\text { Reflexões } \\
\text { sobre tipos de } \\
\text { preconceitos } \\
\text { presentes na } \\
\text { sociedade. } \\
\text { Compreensão } \\
\text { do } \\
\text { funcionamento } \\
\text { de infográficos }\end{array}$ & $\begin{array}{c}\text { Elaborar } \\
\text { coletivamente uma } \\
\text { definição para } \\
\text { preconceito e } \\
\text { infográficos a partir } \\
\text { de conhecimentos } \\
\text { prévios sobre o } \\
\text { gênero }\end{array}$ & $\begin{array}{l}\text { Reconhecer o gênero } \\
\text { infográfico, suas } \\
\text { características e } \\
\text { funcionamento e uso } \\
\text { social para retratar algum } \\
\text { tipo de preconceito. }\end{array}$ \\
\hline $\begin{array}{l}\text { (Instrução aberta) } \\
\text { Criador de } \\
\text { sentidos } \\
\text { Conceitualizar: } \\
\text { nomeando, } \\
\text { teorizando }\end{array}$ & Leitura & $\begin{array}{l}\text { Leitura de } \\
\text { infográficos }\end{array}$ & $\begin{array}{c}\text { Identificar } \\
\text { características e os } \\
\text { efeitos de sentido } \\
\text { que a } \\
\text { multimodalidade/ } \\
\text { multissemiose influi } \\
\text { no gênero } \\
\text { infográfico }\end{array}$ & $\begin{array}{l}\text { Atribuir e produzir } \\
\text { sentidos a mensagens } \\
\text { multimodais/ } \\
\text { multissemióticos }\end{array}$ \\
\hline $\begin{array}{l}\text { (Enquadramento } \\
\text { crítico) } \\
\text { Analista Crítico } \\
\text { Analisar: } \\
\text { funcionalmente, } \\
\text { criticamente }\end{array}$ & $\begin{array}{c}\text { Análise } \\
\text { multissemiótica e } \\
\text { linguística }\end{array}$ & $\begin{array}{l}\text { Análise de } \\
\text { infográficos } \\
\text { estáticos e } \\
\text { animados/ } \\
\text { interativos }\end{array}$ & $\begin{array}{c}\text { Entender como } \\
\text { sentidos são criados } \\
\text { em infográficos } \\
\text { interativos a partir } \\
\text { dos recursos } \\
\text { linguísticos e } \\
\text { semióticos/imagético } \\
\text { s }\end{array}$ & $\begin{array}{l}\text { Analisar criticamente } \\
\text { como os sentidos são } \\
\text { configurados nos designs } \\
\text { de textos multimodais/ } \\
\text { multissemióticos }\end{array}$ \\
\hline $\begin{array}{c}\text { (Prática } \\
\text { transformada) } \\
\text { Transformador de } \\
\text { sentidos } \\
\text { Aplicar: } \\
\text { apropriadamente, } \\
\text { criativamente }\end{array}$ & $\begin{array}{l}\text { Produção textual } \\
\text { (multimodal) }\end{array}$ & $\begin{array}{l}\text { Produção de } \\
\text { infográficos } \\
\text { animado/ } \\
\text { interativo a } \\
\text { respeito de } \\
\text { algum tipo de } \\
\text { preconceito }\end{array}$ & $\begin{array}{c}\text { Produzir um } \\
\text { infográfico estático e } \\
\text { animado/interativo }\end{array}$ & $\begin{array}{l}\text { Produzir textos } \\
\text { multissemióticos como } \\
\text { infográficos. }\end{array}$ \\
\hline
\end{tabular}

Fonte: Autores.

A pesquisa-ação foi realizada no primeiro semestre de 2017, no período de 09 de fevereiro a 30 de abril, com 43 alunos na faixa etária de 16 a 21 anos, de uma turma do $3^{\circ}$ ano do Ensino Médio Integrado do curso Técnico em Mineração. Quando a proposta de pesquisa foi apresentada aos alunos, estes se mostraram muito interessados e dispostos a participar. A partir da organização do material digital, apresentada no Quadro 2, selecionamos, para efeito de análise, apenas as práticas de produção textual, no caso, exemplares de infográficos interativos produzidos pelos alunos participantes da pesquisa.

A escolha por analisar apenas as produções dos infográficos objetiva responder duas questões centrais neste artigo: a) como os alunos se apropriaram dos conceitos estudados durante as oficinas e quais práticas da aprendizagem pelo design foram desenvolvidas durante a produção do gênero? e b) como os alunos se posicionam frente aos temas tratados sobre homofobia em suas produções como analistas críticos e 
construtores de sentidos? Cabe destacar que, embora o trabalho desenvolvido tenha resultado em 15 textos, em função do espaço neste artigo, analisamos apenas um dos infográficos produzidos

\section{Resultados e discussão dos dados}

\subsection{Construindo sentidos pela aprendizagem pelo design: a produção de infográficos contra a homofobia em sala de aula}

As atividades de produção, assim como as demais, apresentavam orientações aos alunos de como deveriam/poderiam produzir um infográfico digital animado/interativo. Para isso, primeiramente apresentamos a eles a plataforma on-line Prezi e informamos que todas as produções seriam feitas a partir dessa ferramenta, sendo que as produções poderiam ser feitas pelas duplas sobre um dos tipos de preconceitos trabalhados durante as oficinas, no caso racismo, homofobia, xenofobia, etc. Embora tenhamos mostrado, durante as oficinas, exemplos de infográficos criados no Canva e no Prezi, cada dupla recriou o seu infográfico à sua maneira, transformando os exemplos iniciais em novos infográficos, realizando, portanto, um redesign.

Como o tema proposto para a produção eram os tipos de preconceitos, os subtemas mais escolhidos pelos alunos foram o racismo e a homofobia (com quatro produções cada) seguidos pelo bullying e xenofobia (com duas produções cada) e, por fim, intolerância religiosa, machismo e cyberbullying (com uma produção cada), conforme Quadro 3.

Quadro 3: Subtemas mais recorrentes para a produção.

\begin{tabular}{|c|c|c|}
\hline & Subtemas mais recorrentes & Quantidade \\
\hline 1 & Racismo & 4 \\
\hline 2 & Homofobia & 4 \\
\hline 3 & Xenofobia & 2 \\
\hline 4 & Bullying & 2 \\
\hline 5 & Intolerância religiosa & 1 \\
\hline 6 & Cyberbulliyng & 1 \\
\hline 7 & Machismo & 1 \\
\hline & Total & $\mathbf{1 5}$ \\
\hline
\end{tabular}

Fonte: Acervo do Grupo NEPLA.

Para a análise referente às produções, objetivando responder às duas questões apresentadas anteriormente, realizaremos 0 seguinte percurso: inicialmente, verificaremos qual categoria (sequencial, relacional ou espacial) sugerida por Ribas (2004) foi escolhida pelo grupo em seu infográfico. Dando prosseguimento, analisaremos como os alunos mobilizaram os processos de conhecimentos da aprendizagem pelo design para construção dos sentidos aos textos produzidos em relação à temática da xenofobia.

Dessa maneira, passemos, agora, à análise do infográfico hipermidiático produzido. 
O exemplar analisado tem como título: "Homofobia no Brasil" e apresenta-se organizado a partir de semioses/linguagens que auxiliam o leitor na compreensão das informações. Vemos que o grupo mobilizou, de forma integrada, essas semioses para constituição hipermidiática do texto e seu sentido, agregando, conforme propõe Ribas (2004) seis características da infografia: multimodialidade/convergência, interatividade, hipertextualidade, customização do conteúdo/personalização, memória, instantaneidade/atualização contínua.

Assim, a categoria escolhida pela dupla para representação do design de sentidos por eles propostos no infográfico foi a sequencial, pois cada quadro/parte do infográfico contém informações que se conectam, sendo cada uma dependente da anterior na construção do sentido global do texto. Um exemplo disso é quando a dupla explica o significado da sigla LGBT (Lésbica, Gays, Bissexuais, Travestis e Transgêneros) e, em seguida, passa a utilizar apenas a sigla ao se referir aos diferentes tipos de orientações sexuais, como mostra a Figura 2:

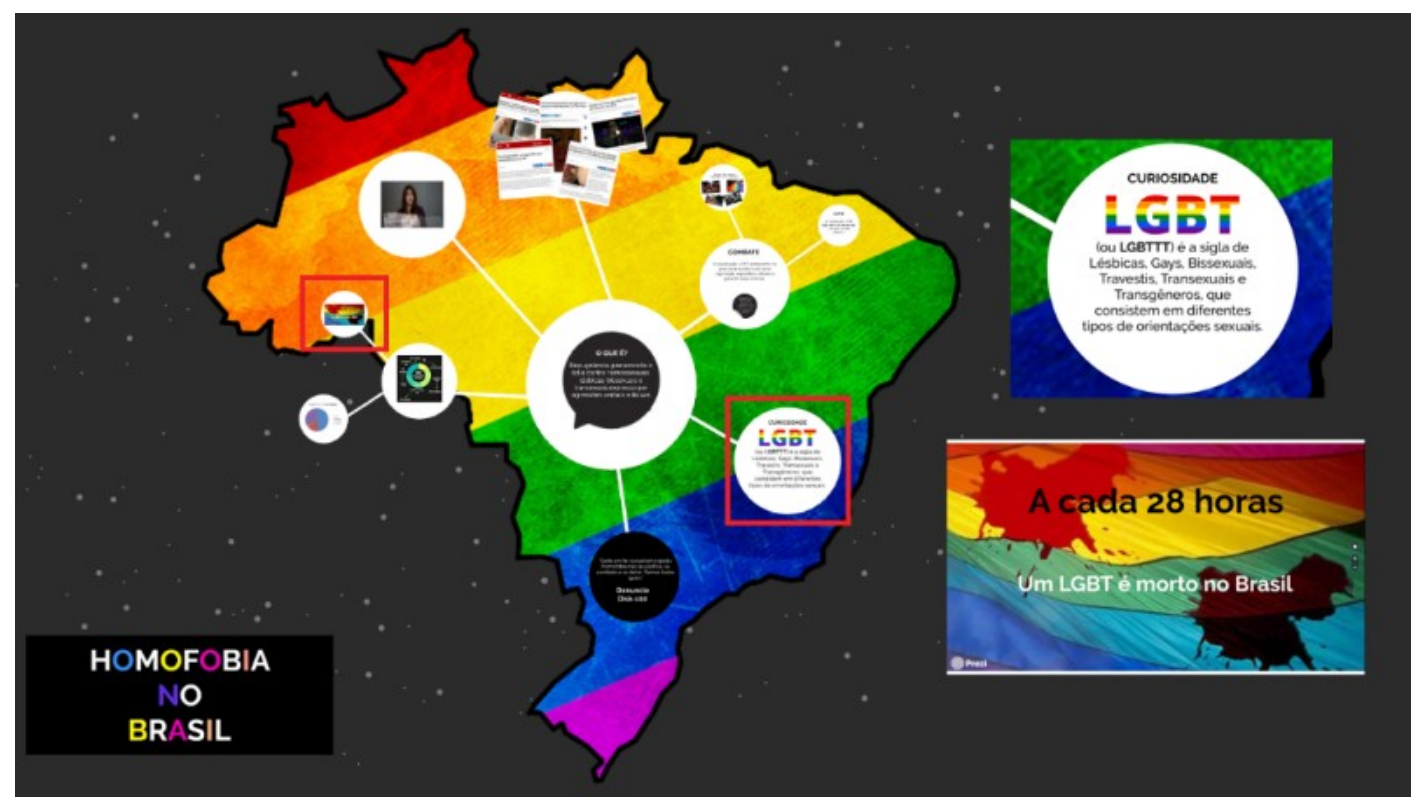

Figura 2: Infográfico hipermidiático - "Homofobia no Brasil". Fonte: Grupo de alunos - IFAP (2017).

No que diz respeito aos processos de conhecimentos da aprendizagem pelo design, percebemos que o grupo parte de uma prática situada. Os alunos experienciam o conhecido, ou seja, trazem à tona o que lhes é familiar a partir de suas vivências, consciência e leituras sobre a questão da homofobia, pois utilizam designs disponíveis available design - tais como reportagens, notícias e dados de outras fontes. Nesse momento, constatamos também que os alunos atuam como analistas críticos e criadores de sentidos a partir da seleção que fazem das informações presentes nessas fontes. Isso porque identificam e relacionam os recursos semióticos (seleção das cores, como na composição da palavra homofobia e no mapa colorido com as cores da bandeira LGBT), para construírem um novo projeto de sentido (design) que, nesse caso, é o infográfico, conforme podemos observar na Figura 3: 


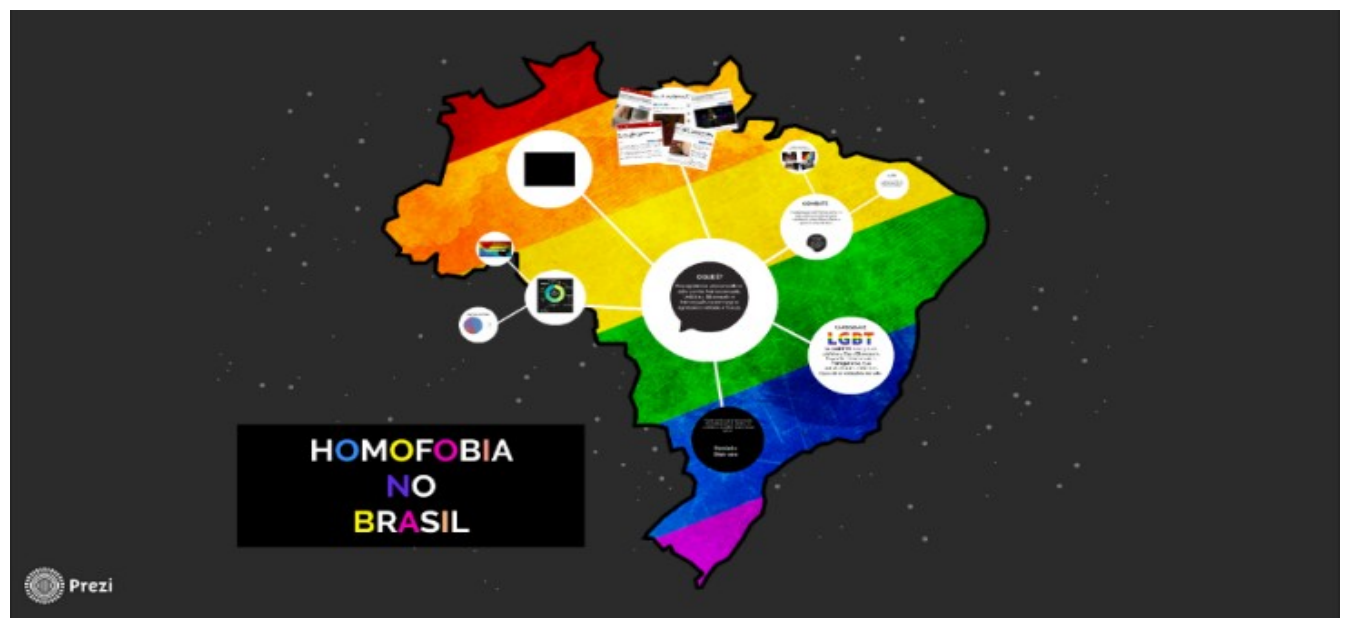

Figura 3: Infográfico hipermidiático - "Homofobia no Brasil".

Fonte: Grupo de alunos - IFAP (2017).

Além disso, os alunos experienciaram o novo, visto que ainda não conheciam bem a ferramenta Prezi, utilizada para a produção do infográfico, como podemos ler no excerto a seguir que, por sua vez, foi retirado do diário de campo da pesquisa. Como é possível constatar, o excerto reproduz interações entre professora/pesquisadora e alunos na oficina de produção do infográfico, conforme Quadro 4:

Quadro 4: Excerto 15 (E15) - Diário de campo (2017).

Professora/pesquisadora: (...) vocês já conheciam o Prezi? ((a pesquisadora/professora aponta para a projeção da tela do Prezi aberta e exibida em um datashow))

Jonas (aluno do grupo): eh... essa ferramenta a gente não conhecia, mas TÊM (ênfase) o Canvas, esse é melhor!

Flávia (aluna de outro grupo): (...) mas o Canvas... não foi aquele que vocês... mostraram ai pra gente? ( ) ((a aluna se direciona para a professora pesquisadora e ao pesquisador))

Douglas (aluno do grupo): (...) vocês não entendem nada, bicho ...tão vendo que eles ((referindo-se à professora/pesquisadora e ao pesquisador)) tão explicando aí que o que eh/ eu também não sei ((risos de todos os alunos da sala))

Pesquisador: (...) o Canvas é bom... mas é só pra infográfico estático (xxx) ((alguns alunos cochicham baixo))

Jonas (aluno do grupo): ah... então, professor ((referindo-se ao pesquisador)) explica aí esse Prezi de novo.

Fonte: Acervo de pesquisa do grupo NEPLA.

No que se refere ao tema, baseando-nos em Bakhtin (2003), podemos dizer que a dupla adota uma postura axiológica/valorativa e ativo-responsiva contrária à temática do preconceito por eles mostrada no conteúdo temático do infográfico (homofobia). Podemos perceber isso nas conclusões que a dupla propõe a partir das palavras "Lute" e "Denuncie". Nesse caso, notamos que novamente os alunos se posicionam como analistas críticos, tanto funcionalmente quanto criticamente a partir das conexões que fazem no design de sentido elaborado e na própria avaliação de sua produção, conforme podemos verificar na Figura 4: 


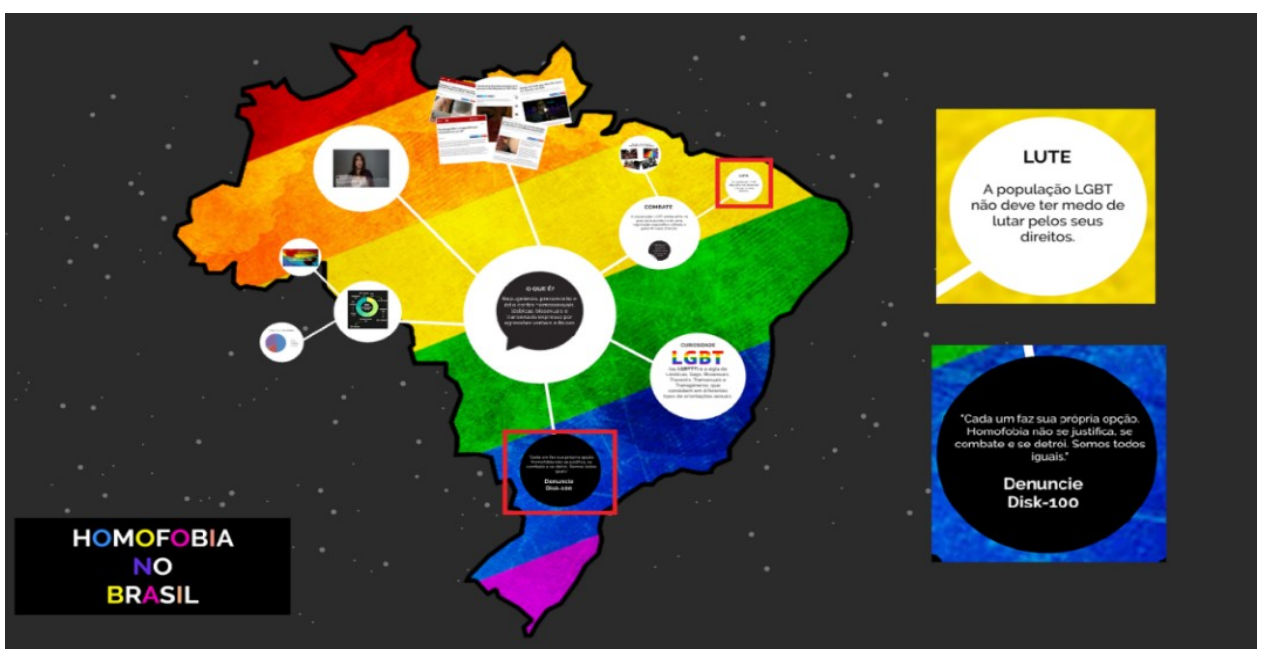

Figura 4: Infográfico hipermidiático - "Homofobia no Brasil".

Fonte: Grupo de alunos - IFAP (2017).

Em relação à prática transformada, consideramos que esta ocorreu não somente ao final da produção, mas durante todo o processo de construção do infográfico bem como do próprio projeto. Isso porque a todo o momento os alunos aplicavam o que aprendiam durante as oficinas de modo apropriado e criativo ao reorganizarem novos sentidos no design do infográfico. Assim, durante o processo de produção do infográfico hipermidiático, é possível dizer que os alunos se configuraram usuários funcionais, pois apresentaram competência técnica na utilização da plataforma Prezi, isto é, digitando, cortando, colando, selecionando informações e imagens do Google, inserindo-as no infográfico e fazendo, portanto, uma curadoria de todas as informações por eles mobilizadas para constituição do trabalho textual.

Na Figura 5, por exemplo, observamos que os alunos fazem prints de algumas manchetes do G1.com, que abordam violências sofridas por homossexuais. Em seguida, o grupo destaca, utilizando imagens, a importância das manifestações (informação relevante) para acabar com esses atos de violência.

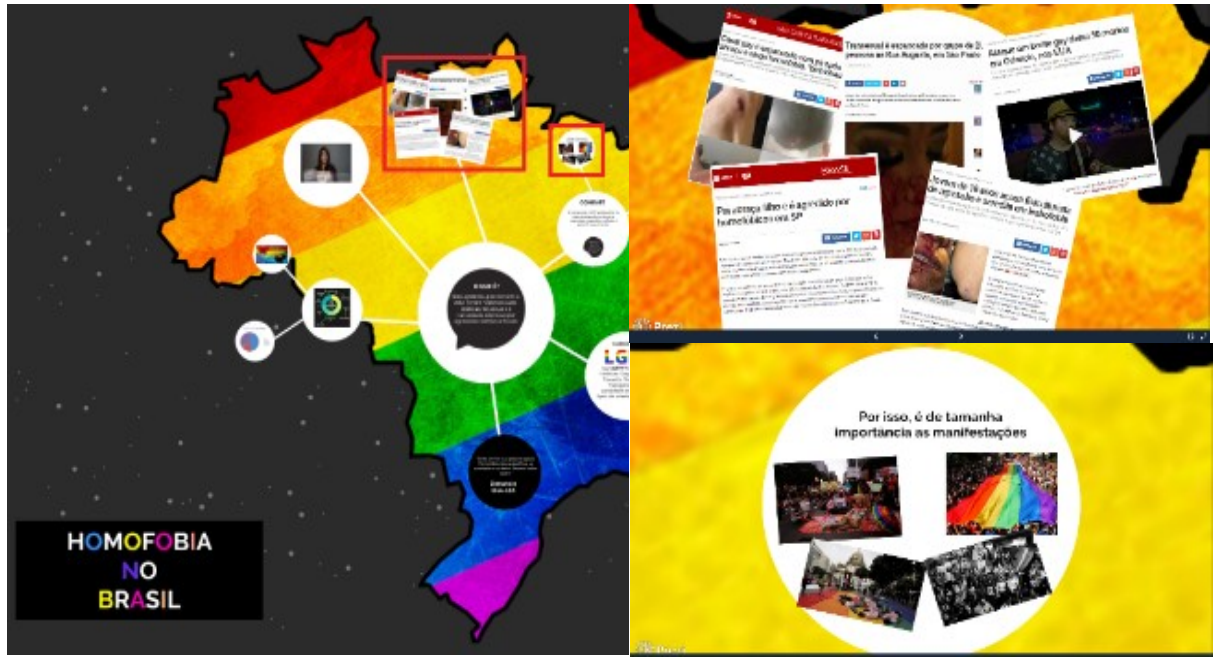

Figura 5: Infográfico hipermidiático - "Homofobia no Brasil". Fonte: Grupo de alunos - IFAP (2017). 
Em síntese, o conjunto de atividades práticas (tanto de leitura quanto de produção) potencialmente pôde auxiliar o trabalho de letramentos digitais e de práticas de multiletramentos (críticos e protagonistas) com alunos participantes do projeto. Essas atividades possibilitaram a eles colocarem-se como produtores ativos de artefatos digitais e culturais do mesmo modo que colocou-os como autores, não meros reprodutores de outros discursos. Além disso, possibilitou aos estudantes analisarem a variedade de efeitos de sentido da multissemiose/multimodalidade. Em outras palavras, foi possível compreender como a mistura de elementos visuais (cores, gráficos, ícones, ilustrações) e verbais, no infográfico, pôde contribuir com a construção textual, marcada por perspectivas sociais, políticas e ideológicas, aspectos estes observados através dos recortes do infográfico analisado.

\section{6 À guisa de conclusão... Algumas considerações}

Neste artigo, intentamos apresentar alguns dados referentes a uma pesquisa-ação no formato de um projeto-piloto com alunos do $3^{\circ}$ ano do Ensino Médio Técnico do IFAP a fim de trabalhar com práticas de letramentos digitais, mais especificamente de produção de infográficos hipermidiáticos a respeito do tema "tipos de preconceito", sendo utilizado como recurso para a produção dos alunos o software Prezi.

Para o recorte de análise, selecionamos dados que nos permitiram compreender como os alunos se apropriaram dos conceitos estudados durante a realização do projeto e quais práticas de multiletramentos de produção de textos multissemióticos foram desenvolvidas por eles nesse processo. É necessário destacar que não foi exigido dos alunos, claramente, produções parecidas com a que vemos nos jornais e revistas, levando-se em consideração que o nosso alunado não possui conhecimento específico, isto é, não é especialista, mas usuário e leitor desse gênero.

Através do resultado das análises, verificamos que efetivamente os alunos se apropriaram tanto dos elementos constitutivos do gênero discursivo infográfico hipermidiático, tais como tema, estilo de linguagem e estrutura composicional, quanto de uma das categorias estudadas durante o projeto: a sequencial (RIBAS, 2004). Além disso, constatamos também que os alunos desenvolveram práticas multiletradas a partir dos princípios da aprendizagem pelo design na produção do gênero multimodal infográfico hipermidiático, o que contribuiu com a ampliação de uma educação linguística crítica e cidadã. Isso ocorreu porque os estudantes tiveram em vista, durante vários momentos de debates, inquietudes, questionamentos e pontos de vista sobre o tópico da homofobia e o modo como esse tipo de preconceito tem sido marcado discursivamente na sociedade.

Assim, consideramos que pode ser proveitoso para as práticas do letramento escolar, a partir da pedagogia dos multiletramentos e pela aprendizagem por design, explorar possibilidades de aprendizagem em ambientes digitais com atividades que sejam relevantes para o ensino de Língua Portuguesa no sentido de estimular aprendizagens no âmbito do letramento digital em relação à leitura de gêneros multissemióticos, que devem ocorrer de forma crítica, considerando o protagonismo de nossos alunos referente aos textos e às práticas discursivas que circulam atualmente tanto em redes sociais quanto em meios de comunicação diversos e com os quais os alunos têm contato. 


\section{Referências}

ANDRÉ, M. E. D. A. Etnografia da prática escolar. Campinas: Papirus, 1995.

BAGNO, M.; RANGEL, E. O. Tarefas da educação linguística no Brasil. Revista Brasileira de Linguística Aplicada, Belo Horizonte, v. 5, n. 1, p. 63-81, 2005. Disponível em: http://www.scielo.br/pdf/rbla/v5n1/04.pdf. Acesso em: 20 fev. 2020.

BAKHTIN, M. Estética da criação verbal. 4. ed. Trad. P. Bezerra. São Paulo: Martins Fontes, 2003.

BELL, HOOKS. Ensinando a transgredir - a educação como prática da liberdade. Martins Fontes. São Paulo, 2013 [1994].

BRASIL. Ministério da Educação. Base Nacional Comum Curricular. Brasília: MEC, 2018. Disponível em: http://basenacionalcomum.mec.gov.br/images/BNCC_EI_EF_110518_versaofinal_site.pdf. Acesso em: 4 mar. 2020.

CANDAU, V. M. Multiculturalismo e educação: desafios para a prática pedagógica. In: MOREIRA, A. F.; CANDAU, V. M. (orgs.). Multiculturalismo: diferenças culturais e práticas pedagógicas. 2 ed. Petrópolis, Rio de Janeiro: Vozes, 2008. p. 13-37.

COPE, B.; KALANTZIS, M. (ed.). Multiliteracies: literary learning and the design of social futures. London: Routledge, 2000.

COPE, B.; KALANTZIS, M. (orgs.) Multiliteracies: literacy learning and the design of social futures. New York: Routledge, 2006.

COPE, B.; KALANTZIS, M. Multiliteracies: New literacies, new learning. Pedagogies: An International Journal, Londres, v. 4. 2009. p. 164-195.

COPE, Bill; KALANTZIS, M. A Pedagogy of Multiliteracies: Learning by design. Londres: Palgrave, 2015.

DE PABLOS, J. M. Infoperiodismo. El Periodista como Creador de Infografia. Madrid, Editorial Síntesis, 1999.

DE PIETRO, J.-F.; SCHNEUWLY, B. O modelo didático de gênero: um conceito da engenharia didática. In: NASCIMENTO, E. L. (org.). Gêneros textuais: da didática de línguas aos objetos de ensino. Campinas: Pontes Editores, 2014. p. 51-81.

DUBOC, A. P. M. Atitude Curricular: Letramentos Críticos nas Brechas da Sala de Aula de Línguas Estrangeiras. 1. ed. Jundiaí: Paco Editorial, 2015.

FERNÁNDEZ-LADREDA, R. C. Infográficos multimedia: el mejor ejemplo de noticias hipertextuales, Mediaccionline. mayo de 2004. Disponível em: 
http://www.mediaccion.com/mediaccionline/temas/periodigital/object.php?o=162. Acesso em: abr. 2020.

FERREIRA, A. J. Educação Linguística Crítica e Identidades Sociais de Raça. In: PESSOA, R. R.; SILVESTRE, P. V.; MONTE MÓR, W. (orgs.). Perspectivas Crítica de Educação Linguística no Brasil: Trajetórias e práticas de professoras(es) universitárias (os) de Inglês. São Paulo: Pá de Palavra, 2018, v. 1, p. 41-48.

FOUCAULT, M. A arqueologia do saber. Rio de Janeiro: Forense Universitária, 1997.

FREIRE, P. Pedagogia da autonomia: saberes necessários à prática educativa. 28. ed. São Paulo: Paz e Terra, 2003.

GNL. A pedagogy of multiliteracies: designing social futures. In: COPE, B.; KALANTZIS, M. (orgs.) Multiliteracies: literacy learning and the design of social futures. Routledge: Psychology Press, 1996. p. 60-92.

GOMES, R. Leitura de gêneros multissemióticos e multiletramentos em materiais didáticos impressos e digitais de Língua Portuguesa do Ensino Médio. 2017. 257 f. Tese (Doutorado em Linguística Aplicada) - Universidade Estadual de Campinas, Campinas, 2017a. Disponível em: http://repositorio.unicamp.br/bitstream/REPOSIP/325318/1/Gomes_Rosivaldo_D.pdf. Acesso em: 05 mai. 2020.

GOMES, R. Materiais didáticos digitais e novos (multi)letramentos: caminhos para um webcurrículo. Projeto de pesquisa. Departamento de Pesquisa da Universidade Federal do Amapá, Macapá, 2017b.

HAMILTON, M. Sustainable literacies and the ecology of lifelong learning. In: HARRISON, R. R. F.; HANSON, A.; CLARKE, J. (orgs.). Supporting lifelong learning. V. 1: Perspectives on learning. London: Routledge; Open University Press, 2002. p. 176-187.

JORDÃO, C. M.. Uma Jornada Crítica em Retrospecto, ou de como se respira no mar. In: PESSOA, R. R.; SILVESTRE, P. V.; MONTE MÓR, W. (orgs.). Perspectivas Crítica de Educação Linguística no Brasil: trajetórias e práticas de professoras(es) universitárias (os) de Inglês. São Paulo: Pá de Palavra, 2018. p. 69-80.

KALANTZIS, M. COPE, B. Learning by Design Project Group. Learning by Design. Melbourne, VIC: Victorian Schools Innovation Commission \& Common Ground, 2005.

KALANTZIS, M. COPE, B. Literacies. Cambridge University Press, Cambridge UK, 2012.

MACHADO, A. R.; CRISTOVÃO, V. L. L. A construção de modelos didáticos de gêneros: aportes e questionamentos para o ensino de gêneros. In: ABREU-TARDELLI, L. S.; CRISTOVÃO, V. L. L (orgs.). O ensino e a aprendizagem de gêneros textuais. Campinas: Mercado de Letras, 2009. p. 123-151.

MAIA, J. O. Tecnologias digitais e educação transformativa: potencialidades para 
formação crítica e participação social mais ampla de vozes locais. In: ROCHA, C. R.; BRAGA, D. B. (orgs.). Políticas linguísticas, ensino de línguas e formação docente: desafios em tempos de globalização e internacionalização. Campinas: Pontes, 2015, v. 11 , p. 155-174.

MENEZES DE SOUZA, L. M. T. Engaging the global by resituating the local. In: ANDREOTTI, V. O.; MENEZES DE SOUZA, L. M. T. Postcolonial perspectives on global citizenship education. New York e London: Routledge, 2012.

MOITA LOPES, L. P. Identidades fragmentadas. A Construção Discursiva de Raça, Gênero e Sexualidade na Escola. Campinas: Mercado de Letras, 2002.

MOITA LOPES, L. P. (org.) Por uma Linguística Aplicada Indisciplinar. São Paulo: Parábola, 2006.

MONTE MÓR, W. Sobre rupturas e expansão na visão de mundo: seguindo as pegadas e os rastros da formação crítica. In: PESSOA, R. R.; SILVESTRE, P. V.; MONTE MÓR, W. (orgs.). Perspectivas Crítica de Educação Linguística no Brasil: Trajetórias e práticas de professoras(es) universitárias (os) de Inglês. São Paulo: Pá de Palavra, 2018, p. 265-278.

PEREIRA, A. L. Construção de criticidade em espaços de atuação religiosa, política e acadêmica. In: PESSOA, R. R.; SILVESTRE, P. V.; MONTE MÓR, W. (orgs.). Perspectivas Crítica de Educação Linguística no Brasil: Trajetórias e práticas de professoras(es) universitárias (os) de Inglês. São Paulo: Pá de Palavra, 2018. p. 49-59.

RIBAS, B. Infografia Multimídia: um modelo narrativo para o webjornalismo. In: ENCONTRO NACIONAL DE JOVENS PESQUISADORES EM JORNALISMO (II JPJOR). Anais... Salvador: $\quad$ Bahia, 2004. Disponível em: http://www.facom.ufba.br/jol/pdf/2004_ribas_infografia_multimidia.pdf. Acesso em: 09 mar. 2020.

ROCHA, C. H.; AZZARI, E. Tecnologias digitais e educação crítica em língua estrangeira: um relato de experiência à luz dos letramentos. In: JESUS, D.; CARBONIERI, D. (orgs.) Práticas de Multiletramentos e letramento crítico: outros sentidos para a sala de aula de línguas. Campinas, SP: Pontes Editores, 2016. p. 157-182.

ROJO, R. H. R. Pedagogia dos multiletramentos: diversidade cultural e de linguagens na escola. In: ROJO, H. R. R; MOURA, E. (orgs.) Multiletramentos na escola. São Paulo: Parábola, 2012.

ROJO, R. H. R. Entre Plataformas, ODAs e Protótipos: Novos multiletramentos em tempos de WEB2. The ESPecialist: Descrição, Ensino e Aprendizagem, v. 38, n. 1, jan-jul 2017, p. 5-25. Disponível em: https://revistas.pucsp.br/index.php/esp/article/view/32219. Acesso em: 14 abr. 2020.

ROJO, R. H. R. O Letramento Escolar e os Textos da Divulgação Científica - A Apropriação Dos Gêneros de Discurso na Escola. Linguagem em (Dis) curso - LemD, v. 8 , n. 3, p. 581-612, set. /dez.2008. Disponível em: 
http://www.scielo.br/scielo.php?script=sci_arttext\&pid=S1518-76322008000300009.

Acesso em: 21 fev. 2020.

ROJO, R. H. R.; MOITA LOPES, L. P. Linguagens, códigos e suas tecnologias. In: BRASIL. Ministério da Educação. Secretaria de Educação Básica. Departamento de Políticas de Ensino Médio. Orientações curriculares de ensino médio. Brasília, DF, 2004. p. 14-56.

SANTAELLA, L. Gêneros discursivos híbridos na era da hipermídia. São Paulo: Bakhtiniana, 2014. p. 206-216.

SANTOS, B. S. Para além do Pensamento Abissal: das linhas globais a uma ecologia de saberes. Revista Crítica de Ciências Sociais, v. 78. 2007. Disponível em: http://www.scielo.br/pdf/nec/n79/04.pdf. Acesso em: 22 fev. 2020.

SIGNORINI, I. Letramentos multi-hipermidiáticos e formação de professores de língua. In: FIAD, R. S. (orgs.). Ensino de língua: das reformas, das inquietações e dos desafios. Belo Horizonte: Editora da UFMG, 2012. p. 283-304.

SOUZA, A. L. S. letramentos de reexistência: poesia, grafite, música, dança: hip hop. São Paulo: Parábola Editorial, 2011.

THIOLLENT, M. Metodologia da Pesquisa-Ação. 6 ed. São Paulo: Cortez, 1994.

VALERO SANCHO, J. L. La comunicación de contenidos en la infografía digital. In: Estudios sobre El Mensaje Periodístico, v. 16. 2010. Disponível em: https://revistas.ucm.es/index.php/ESMP/article/view/ESMP1010110469A. Acesso em: 05 mai. 2020.

VIDEIRA, P. L. Marabaixo, dança afrodescendente: Significando a identidade étnica do negro amapaense. Fortaleza: UFC, 2009. 